\title{
Epidemiology of bitter crab disease (Hematodinium sp.) in snow crabs Chionoecetes opilio from Newfoundland, Canada
}

\author{
Jeffrey D. Shields ${ }^{1, *}$, David M. Taylor ${ }^{2}$, Stephen G. Sutton ${ }^{2}$, Paul G. O'Keefe ${ }^{2}$, \\ Danny W. Ings ${ }^{2}$, Amanda L. Pardy ${ }^{2}$ \\ ${ }^{1}$ Virginia Institute of Marine Science, The College of William and Mary, Gloucester Point, Virginia 23062, USA \\ ${ }^{2}$ Department of Fisheries and Oceans, CP5567, White Hills, St. John's, Newfoundland A1C 5X1, Canada
}

\begin{abstract}
The parasitic dinoflagellate Hematodinium sp. causes a condition known as bitter crab disease (BCD) in snow crabs Chionoecetes opilio and Tanner crabs C. bairdi. As the name of the condition implies, crabs infected with BCD are unmarketable due to their bitter flavor. We surveyed the distribution of BCD in 3 regions within the snow crab fishery of Newfoundland from 1997 to 2003. Over time, the disease has become firmly established in Conception and Bonavista Bays and persists at low levels on the Avalon fishing grounds. An epizootic occurred within Bonavista and Conception Bays in 1999 and persisted in Conception Bay in 2000, reaching prevalences of over $2 \%$ to $9 \%$ in trapped and trawled male crabs and from 19 to $26 \%$ in trawled and trapped female crabs, respectively. Infections were highest in females and small males, i.e. the unfished and pre-recruit portions of the fishery. In a mortality study, all of the naturally infected crabs died and $50 \%$ of the experimentally inoculated crabs died. Patterns in the molting cycle and prevalence of infection indicate that transmission occurs during the post-molt condition, and that overt infections probably develop 2 to 4 mo later with mortalities occurring at least 3 to 4 mo thereafter. The hydrography of this bay may have contributed to the epizootic as infections were centered within the deeper confines of the bay. Analysis of various abiotic factors uncovered a significant positive association between prevalence, depth and mud/sand substrates; the nature of this relationship was not apparent but may be related to diet or alternate hosts. Lastly, given the increase in BCD in snow crabs in Newfoundland, we recommend that fishery management programs for Chionoecetes fisheries employ non-selective gear to monitor for Hematodinium infections in female and juvenile crabs because these under-sampled members of the population may forewarn of impending recruitment declines that might otherwise remain unexplained.
\end{abstract}

KEY WORDS: Ecology $\cdot$ Prevalence $\cdot$ Host factors $\cdot$ Abiotic factors $\cdot$ Transmission $\cdot$ Dinoflagellate

\section{INTRODUCTION}

The snow crab Chionoecetes opilio supports the largest commercial fishery in Newfoundland. In 2003, landings for this fishery were in excess of $58000 \mathrm{t}$ with an ex-vessel value of approximately CAN $\$ 300$ million. Bitter crab disease (BCD) was first observed in snow crabs off Newfoundland in 1990 where it was reported at very low levels $(0.037 \%)$ (Taylor \& Khan 1995). The disease is now established in the productive fisheries of the inshore northern and eastern bays within the Northwest Atlantic Fishing Organization's (NAFO) Division 3L (Taylor \& Khan 1995, Pestal et al. 2003), and in some deep-water offshore areas of NAFO Divisions 2J, 3L and 3K (Dawe 2002), but there is significant concern that it may be spreading to other locations. Recent surveys in Conception Bay on the east coast of Newfoundland have revealed that the 
prevalence of disease has increased markedly since 1996, reaching 1.60 and $6.34 \%$ in male and female crabs, respectively, in 1998 (Pestal et al. 2003).

Bitter crab disease is caused by an unusual parasitic dinoflagellate, Hematodinium sp. (Meyers et al. 1987). The bitter flavor of the meat of infected crabs is thought to arise from physiological changes to the host from long-term, chronic infections by the protozoan (Meyers et al. 1987, Eaton et al. 1991). Unfortunately, a single infected crab can ruin an entire batch during bulk processing of crab meat or sections (D. M. Taylor pers. obs.). BCD has been reported in Chionoecetes bairdi and C. opilio from SE Alaska (Meyers et al. 1987, 1990), in C. opilio from the Bering Sea (Meyers et al. 1996), and in C. tanneri from British Columbia (Bower et al. 2003). At present, it is not clear if the same species of Hematodinium occurs in Alaska, British Columbia and Newfoundland, but this is an important issue that should be resolved by studies on the molecular biology of the parasite.

Outbreaks of Hematodinium spp. have damaged many crustacean fisheries. In Alaska, the Tanner crab (Chionoecetes bairdi) fishery has suffered localized declines due to Hematodinium sp. (Meyers et al. 1987, 1990, Eaton et al. 1991). Focal outbreaks have occurred in enclosed embayments and fjords with shallow sills (Meyers et al. 1987, 1990, 1996). Similarly, in the coastal bays of Virginia and Maryland, the blue crab (Callinectes sapidus) fishery has suffered annual mortalities in high-salinity waters, but the larger, riverine fishery has not been affected (Messick 1994, Messick \& Shields 2000). In Scotland, the Norway lobster (Nephrops norvegicus) fishery lost an estimated $£ 2$ to 4 million in an outbreak of a Hematodinium-like parasite (Field et al. 1992), and the parasite has remained in that fishery at sustained levels (35 to $50 \%$ ) through several years (Field \& Appleton 1995, Stentiford et al. 2001). In France, the velvet crab (Necora puber) fishery suffered a catastrophic decline (>96\%) due to H. perezi (Wilhelm \& Miahle 1996), and stocks of the edible crab Cancer pagurus were also heavily infected (Latrouite et al. 1988, Stentiford et al. 2002). Thus, the presence of the dinoflagellate in any fishery appears to be a significant cause for concern.

Mortality studies with Tanner crabs, Norway lobsters and blue crabs infected with Hematodinium spp. indicate that infections are generally fatal to the host (Meyers et al. 1987, Eaton et al. 1991, Field et al. 1992, Shields \& Squyars 2000). Naturally infected adult Tanner crabs survived from 20 to $158 \mathrm{~d}$ in the laboratory (Meyers et al. 1987), but in other trials infected crabs survived for over $400 \mathrm{~d}$ (Love et al. 1993). Naturally infected adult Norway lobsters had mortality rates 2 to 4 times higher than uninfected lobsters, with most of the deaths occurring early in the course of the experi- ment (Field et al. 1992). Experimentally infected blue crabs experienced $87 \%$ mortality over $40 \mathrm{~d}$, but in a few cases hosts were refractory to infection (Shields \& Squyars 2000). There is evidence that low temperatures and low salinities limit the proliferation of the parasite in blue crabs (Messick et al. 1999), but the parasite in snow crabs thrives at low temperatures and would likely not be subjected to low salinities.

Host factors show some distinct correlations with infection. Juvenile snow and blue crabs and Norway lobsters have a significantly higher prevalence of Hematodinium spp. infections than adults (Messick 1994, Field et al. 1998, Messick \& Shields 2000, Stentiford et al. 2001, Dawe 2002, Pestal et al. 2003). However, infections in Tanner crabs from SE Alaska show few differences between sexes (Meyers et al. 1987, 1990), presumably because the high prevalences mask more subtle host factors, but these studies used commercial traps and did not sample small crabs. Such differences in prevalence may reflect either the intense fishing pressure on the males, a predilection of the disease for the smaller size classes of hosts, or increased mortalities in larger crabs.

In 1993, we began incorporating the prevalence of BCD into annual assessments of snow crab stocks in 3 survey areas off the NE coast of Newfoundland. By 1997, monitoring of BCD was fully incorporated into the assessments. Here we report on data collected from 1997 to 2003. The primary goal of the monitoring program was to assess the importance of the disease to Newfoundland's snow crab fishery. The objectives were (1) to document the distribution and prevalence of BCD in snow crabs from 3 hydrographically different regions (Conception Bay, Bonavista Bay, and Avalon), (2) to assess the biotic and abiotic factors that affected the distribution and abundance of the disease, and (3) to analyze differences in trawl and trap surveys that may have affected estimates of prevalence in snow crab populations. In addition, to more fully understand the effect of the disease in snow crabs, we examined the mortality rate of overtly infected crabs with that of uninfected ones.

\section{MATERIALS AND METHODS}

Survey sites. The study sites were Conception Bay, Bonavista Bay, and an area 3 to 45 nautical miles off the NE Avalon Peninsula (Fig. 1). These sites, which are all situated on the northeast coast of Newfoundland, have features that make them distinct from each other. Bonavista Bay, the most northerly, is a partially enclosed deep-water bay which has a steep sill at its mouth. The bottom type consists of thick mud on the commercial crab grounds. Commercial crab fishing is 


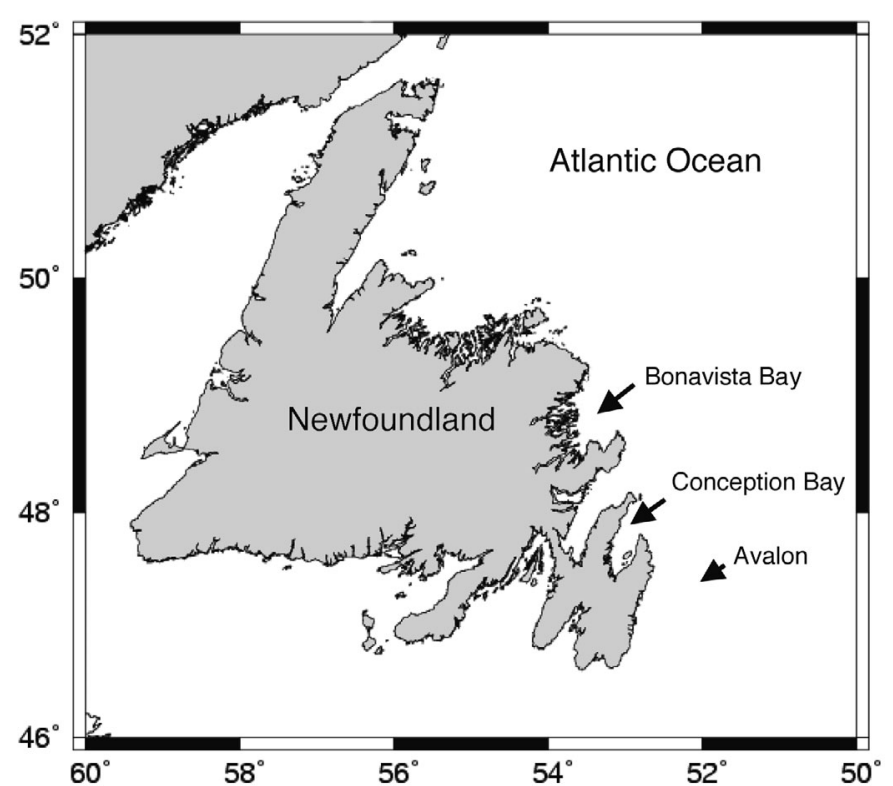

Fig. 1. Location of study sites off Newfoundland

usually concentrated in areas where water depth exceeds $270 \mathrm{~m}$. Conception Bay is also partially enclosed, but has a more diverse bottom type on the fishing grounds, ranging from sand and gravel at the mouth to thick mud in the inner deep basin. Commercial crab fishing is conducted from 130 to $250 \mathrm{~m}$. The Avalon study area off the Avalon Peninsula is in open ocean with a bottom type consisting of sand and gravel. Commercial fishing depths are confined here, averaging $190 \mathrm{~m}$. The bottom temperature in this study site is colder than in the others as its relative shallowness exposes it to the full effect of the Labrador Current.

The surveys took place during the Department of Fisheries and Oceans (DFO) annual stock assessment research cruises. Sampling at Avalon took place in May and June, at Bonavista Bay in August, and at Conception Bay in September and October. Briefly, stations were chosen randomly and stratified by depth using a computer program for randomization. Crabs were sampled at each station with either a trawl, or a fleet of traps, or both as in Pestal et al. (2003). A lined No. 36 shrimp bottom trawl with footgear modified to maximize snow crab capture and retention along with SCANMAR sensors was towed for $10 \mathrm{~min}$ at a speed of 2.5 knots. Traps were deployed in 'fleets' of standard Japanese conical traps, 8 of which had $13.3 \mathrm{~cm}$ mesh and 2 of which had $2.3 \mathrm{~cm}$ mesh. The number of standard Japanese traps per 'fleet' varied from 4 to 8 over the study period, due to other research goals in some years which required using traps of varying mesh sizes. Further details regarding baiting of traps and the shipboard sampling of crabs are given in Pestal et al.
(2003). The primary substrate type was determined from the contents of each trawl as mud, sandy mud, sand, gravel, fine gravel and shell, rock, boulders and other. The substrates were condensed to 3 categories for analysis: mud/sand, gravel/shell, rock/boulder.

Sex, carapace width (CW), shell condition, maturity status (for females) and macroscopic signs of bitter crab disease were noted for crabs that were examined. Shell condition was determined using criteria described by Taylor et al. (1989). Briefly, shell categories are Shell 1 (soft, recent molt), Shell 2 (recently hard, molted within last year), Shell 3 (fouled, not molted within $2 \mathrm{yr}$ ) and Shell 6 (intermediate, not molted within last year). For diagnosis of $\mathrm{BCD}$, the gross macroscopic sign of infection with Hematodinium is a distinct color change to the carapace that gives the crabs a cooked appearance (Pestal et al. 2003). These heavily infected individuals also have an opaque, solid white ventrum, listless or lethargic behavior, and milky, discolored hemolymph (Meyers et al. 1990, Taylor \& Khan 1995). In some cases crabs suspected of having infection were further diagnosed by removal of the carapace and examination of the heart. Histological analysis $(\mathrm{n}=12$ ) confirmed that cream-colored hearts were indicative of infection compared to the translucent, beige color of normal healthy hearts, and in no cases were other hemolymph parasites present (unpubl. data).

Mortality study. In controlled laboratory experiments, the mortality rates of experimentally and naturally infected hosts were examined. Due to space limitations and collection bias, these experiments were undertaken with relatively small numbers of male and female crabs. Crabs were held in 6001 aquaria with flow-through running seawater at $4^{\circ} \mathrm{C}$. Treatments consisted of an experimental group of naturally infected crabs, an experimental group of crabs injected with known aliquots of Hematodinium sp. (see below), and a control group of uninfected individuals injected with the support buffer used for preparations of aliquots. Mortality was censused at weekly intervals and analyzed via survival analysis (Cox \& Oakes 1984).

For inoculations with Hematodinium sp., hemolymph was drawn from infected individuals and pooled into support buffer, a physiological saline consisting of $\mathrm{NaCl}$, $27.99 \mathrm{gl}^{-1}, \mathrm{KCl} 0.95 \mathrm{gl}^{-1}, \mathrm{CaCl}_{2} 2.014 \mathrm{~g} \mathrm{l}^{-1}, \mathrm{MgSO}_{4} 2.465$ $\mathrm{g} \mathrm{l}^{-1}, \mathrm{Na}_{2} \mathrm{SO}_{4} 0.554 \mathrm{gl}^{-1}$, HEPES $1.92 \mathrm{gl}^{-1}$, adjusted to $\mathrm{pH}$ 7.8 , with added glucose $\left(1.0 \mathrm{mg} \mathrm{ml}^{-1}\right)$ after Appleton \& Vickerman (1998). Amoeboid cells of Hematodinium sp. were counted in a hemacytometer ( 5 replicates) and aliquoted in buffer to give an estimated dose of $1.0 \times 10^{5}$ parasites which was injected into uninfected crabs.

At biweekly intervals, hemolymph samples were drawn from experimentally inoculated and control crabs as in Pestal et al. (2003). Briefly, hemolymph 
samples were drawn into individual $3 \mathrm{ml}$ syringes with a 23ga needle preloaded with $1 \mathrm{ml}$ ice-cold, $10 \%$ formalin in filtered seawater at a proportion of $1: 2$ to 1:5 hemolymph to fixative. The fixed hemolymph was gently shaken and refrigerated until processed. In the laboratory, aliquots of fixed hemolymph were placed on poly-L-lysine-coated slides, allowed to settle for $45 \mathrm{~s}$, post-fixed in Bouin's solution for $24 \mathrm{~h}$, and transferred to $70 \%$ ethanol for holding. Smears were hydrated, stained with Jenner-Giemsa for 10 to $20 \mathrm{~min}$ (Presnell \& Schreibmann 1997), dehydrated through an acetone series, cleared in a xylene series, and mounted in cytoseal. Stained smears were examined with a light microscope at $400 \times$ and classified as 'infected' when at least 1 clearly identifiable Hematodinium cell of any stage was found (Meyers et al. 1987, Taylor \& Khan 1995).

Statistical analysis. Logistic regression and chisquare were used to analyze possible differences in host and environmental factors in relation to infection. The proportional hazards model (Kaplan-Meier) with the Weibull distribution was used to examine survival data and the Tarone-Ware log-rank test was used to examine differences between survivorship curves (Wilkinson 1997). Size classes represent $5 \mathrm{~mm}$ increments (i.e. $90 \mathrm{~mm}$ class includes 90 to $94 \mathrm{~mm}$ crabs).

Snow crabs sampled by trawling in Conception Bay from 1997 to $2000(n=15803)$ were used to assess the effects of biotic and abiotic variables in relation to the prevalence of BCD. Crabs sampled from Bonavista Bay and the Avalon fishing grounds were not used in this analysis because BCD prevalence was significantly lower in these areas, and we wished to avoid possible confounding of the results by a location effect. Prevalence is the number of infected crabs divided by the total number sampled.

Logistic regression was used to model the effects of biotic and abiotic variables on the probability of a crab being infected with $\mathrm{BCD}$. The logistic regression model took the following form:

$$
\ln (\mathrm{p} / 1-\mathrm{p})=\alpha+\Sigma \beta_{\mathrm{i}} \mathrm{X}_{\mathrm{i}}
$$

where $\mathrm{p}=$ probability of a given individual being infected with $\mathrm{BCD}_{;}(\mathrm{p} / 1-\mathrm{p})=$ odds of a given crab being infected with $\mathrm{BCD} ; \alpha=$ constant; $\beta=$ vector of regression parameters; and $\mathrm{X}=$ vector of independent variables for categorical variable $i$. Interpretation of the fitted model is based on the odds ratio which is the odds of a crab being infected with BCD at one level of an independent variable divided by the odds of a crab being infected with BCD at another (lower) level of that independent variable (with all other independent variables held constant). An odds ratio greater than 1.0 indicates that the odds of a crab being infected with $\mathrm{BCD}$ are a positive function of the independent vari- able, whereas an odds ratio less than 1.0 indicates that the odds of a crab being infected are a negative function of the independent variable. Odds ratios farther from 1.0 indicate a stronger association between the 2 variables (Agresti 1996).

Biotic variables tested for effects on the probability of an individual being infected by BCD were carapace width, sex, maturity stage (for females), and shell condition. Abiotic factors tested were substrate type (classified as either mud/sand, gravel/shells, or rock/boulder) and depth (classified as either $<200 \mathrm{~m}$, $200-250 \mathrm{~m}$, or $>250 \mathrm{~m}$ ). Statistical significance was set at $\alpha=0.05$.

\section{RESULTS}

\section{Temporal and spatial distribution of disease}

Over the 7 yr period of study, 217136 snow crabs were visually examined for overt infections of $\mathrm{BCD}$ (Table 1). Of these, 172743 crabs were caught in traps and 44393 were caught in trawls. Traps showed a significant bias toward large juvenile and adult male crabs whereas trawl samples showed less bias between sexes. Samples were comprised of 70644 crabs from Avalon, 68153 crabs from Bonavista Bay, and 78339 crabs from Conception Bay. Due to logistical constraints, collection periods did not coincide seasonally between regions. Sampling at Avalon took place in May and June, at Bonavista Bay in August, and at Conception Bay in September and October. Further, in Conception Bay, the 2001 trawl data were inadvertently collected with a larger mesh gear than that used normally; these data were thus excluded from the analysis due to poor sample sizes and significant sample bias. Due to logistical constraints on ship and crew time, seasonal differences in prevalence within and between regions could not be examined.

The prevalences of infection of Hematodinium sp. varied markedly between regions, with the Avalon fishing ground showing consistently lower prevalences $(<1.00 \%)$ in both trawl and trap surveys than the other regions (Fig. 2). The prevalences of infection in Bonavista Bay were intermediate (1.00 to $4.93 \%$ ), generally higher than those at Avalon, but almost an order of magnitude lower than those in Conception Bay (2.00 to $26.67 \%$ ). However, some of the differences in prevalence may have been due to seasonal variation in the development of overt infections.

During 1999 and 2000, snow crabs experienced an epizootic of Hematodinium sp. within Bonavista and Conception Bays. In 1999, the prevalence in Bonavista Bay reached 4.93 and $2.96 \%$ in females collected by trap and trawl, respectively. Males also showed 
Table 1. Annual sample sizes for trapped and trawled crabs by region and sex. The Avalon region was sampled in May to June, Bonavista Bay in August, and Conception Bay in September and October

\begin{tabular}{|c|c|c|c|c|c|c|c|c|c|}
\hline $\begin{array}{l}\text { Region, } \\
\text { method }\end{array}$ & Sex & 1997 & 1998 & 1999 & 2000 & 2001 & 2002 & 2003 & Totals \\
\hline $\begin{array}{l}\text { Avalon, } \\
\text { trap }\end{array}$ & $\begin{array}{l}\text { Female } \\
\text { Male }\end{array}$ & $\begin{array}{c}183 \\
1739\end{array}$ & $\begin{array}{c}88 \\
6172\end{array}$ & $\begin{array}{c}467 \\
8024\end{array}$ & $\begin{array}{c}78 \\
6638\end{array}$ & $\begin{array}{c}60 \\
12489\end{array}$ & $\begin{array}{c}218 \\
10428\end{array}$ & $\begin{array}{c}309 \\
12441\end{array}$ & $\begin{array}{c}1403 \\
57931\end{array}$ \\
\hline $\begin{array}{c}\text { Avalon, } \\
\text { trawl }\end{array}$ & $\begin{array}{l}\text { Female } \\
\text { Male }\end{array}$ & $\begin{array}{l}389 \\
575\end{array}$ & $\begin{array}{l}1237 \\
1440\end{array}$ & $\begin{array}{l}1499 \\
1898\end{array}$ & $\begin{array}{l}556 \\
732\end{array}$ & & $\begin{array}{l}335 \\
554\end{array}$ & $\begin{array}{c}892 \\
1203\end{array}$ & $\begin{array}{l}4908 \\
6402\end{array}$ \\
\hline $\begin{array}{r}\text { Bonavista } \\
\text { Bay, trap }\end{array}$ & $\begin{array}{l}\text { Female } \\
\text { Male }\end{array}$ & $\begin{array}{c}70 \\
3036\end{array}$ & $\begin{array}{c}320 \\
8248\end{array}$ & $\begin{array}{l}1644 \\
6630\end{array}$ & $\begin{array}{l}1573 \\
8874\end{array}$ & $\begin{array}{l}1428 \\
6960\end{array}$ & $\begin{array}{c}540 \\
9834\end{array}$ & $\begin{array}{c}861 \\
7023\end{array}$ & $\begin{array}{c}6436 \\
50605\end{array}$ \\
\hline $\begin{array}{l}\text { Bonavista } \\
\text { Bay, trawl }\end{array}$ & $\begin{array}{l}\text { Female } \\
\text { Male }\end{array}$ & $\begin{array}{l}121 \\
191\end{array}$ & $\begin{array}{l}627 \\
829\end{array}$ & $\begin{array}{l}574 \\
890\end{array}$ & $\begin{array}{l}1660 \\
2895\end{array}$ & & $\begin{array}{c}589 \\
2143\end{array}$ & $\begin{array}{l}265 \\
328\end{array}$ & $\begin{array}{l}3836 \\
7276\end{array}$ \\
\hline $\begin{array}{c}\text { Conception } \\
\text { Bay, trap }\end{array}$ & $\begin{array}{l}\text { Female } \\
\text { Male }\end{array}$ & $\begin{array}{c}312 \\
8458\end{array}$ & $\begin{array}{c}19 \\
5421\end{array}$ & $\begin{array}{c}45 \\
7826\end{array}$ & $\begin{array}{c}15 \\
7690\end{array}$ & $\begin{array}{c}36 \\
8911\end{array}$ & $\begin{array}{c}24 \\
8682\end{array}$ & $\begin{array}{c}23 \\
8906\end{array}$ & $\begin{array}{c}474 \\
55894\end{array}$ \\
\hline $\begin{array}{r}\text { Conception } \\
\text { Bay, trawl }\end{array}$ & $\begin{array}{l}\text { Female } \\
\text { Male }\end{array}$ & $\begin{array}{c}81 \\
935\end{array}$ & $\begin{array}{c}660 \\
4047\end{array}$ & $\begin{array}{l}1282 \\
4394\end{array}$ & $\begin{array}{l}1206 \\
3198\end{array}$ & & $\begin{array}{c}172 \\
1700\end{array}$ & $\begin{array}{c}793 \\
3503\end{array}$ & $\begin{array}{c}4194 \\
17777\end{array}$ \\
\hline Totals & & 16090 & 29108 & 35173 & 35115 & 29884 & 35219 & 36547 & 217136 \\
\hline
\end{tabular}

increased prevalences at 1.16 and $1.12 \%$, trap and trawl, respectively. Similarly high prevalences were observed from crabs in Conception Bay (i.e. 9.52 and $2.75 \%$ in females and males from trawls, respectively). Moreover, in 2000, the prevalence of infection in Conception Bay reached highs of 26.67 and $18.24 \%$ in females collected by trap and trawl, respectively, with males also showing high prevalences (2.68 and $8.04 \%$, trap and trawl, respectively). However, by 2000, the prevalences of Hematodinium sp. had returned to low levels in Bonavista Bay and remained low in Avalon. From 2001 and 2002, the trap data indicated that the epizootic in Conception Bay had subsided, but in 2003, the prevalence of infection had risen to 2.88 and $6.95 \%$ in trawled and trapped male crabs, and 4.67 and $6.95 \%$ in trawled and trapped female crabs, respectively. The prevalences remained comparatively low in Avalon and Bonavista Bay during this period, but again, these regions were sampled in different time periods.

The spatial distribution of Hematodinium-infected individuals was examined within the 3 regions over time. No patterns in prevalence were evident for Avalon and Bonavista Bay; the prevalence of diseased individuals was low and infections were widely dispersed throughout each region. However, from 1997 to 2003, most infections in Conception Bay were located at depths greater than $200 \mathrm{~m}$ and well within the deeper confines of the bay (Fig. 3). Prevalence was significantly lower at depths $<200 \mathrm{~m}$ than at depths $>200 \mathrm{~m}$ and depths $>250 \mathrm{~m}(0.40,2.12,2.19 \%$, respectivly, $\chi^{2}=74.81$, df $=2, \mathrm{p}<0.001$ ).

The prevalence of infection was generally higher in trawl surveys compared to trap surveys, primarily because the former caught more juvenile and female

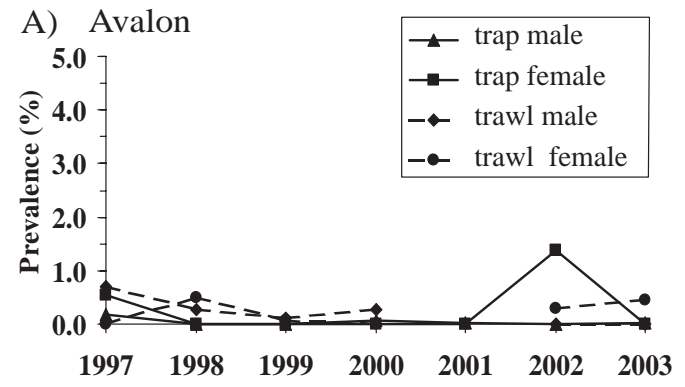

B) Bonavista Bay

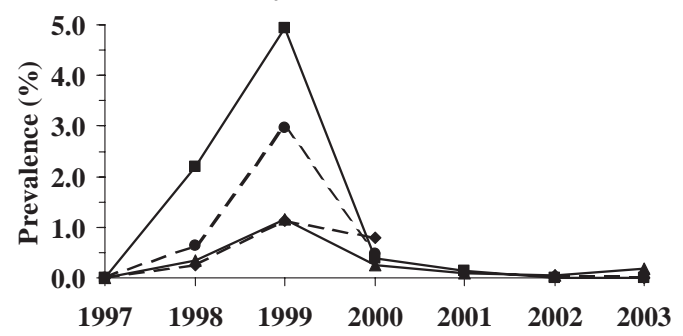

C) Conception Bay

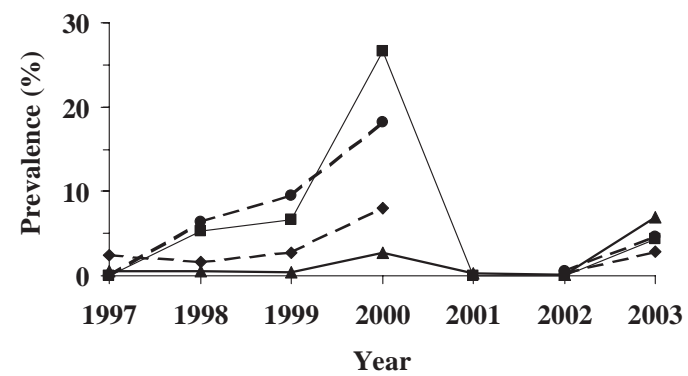

Fig. 2. Hematodinium sp. infecting Chionoecetes opilio. Annual prevalences of bitter crab disease (BCD) in snow crabs from (A) Avalon, (B) Bonavista Bay, and (C) Conception Bay. Trap (solid lines) and trawl (dashed lines) data are separated by sex (male $=\boldsymbol{\Delta}$ or $\bullet$, female $=\boldsymbol{\square}$ or $\bullet$ ). Note change in scale of $y$-axis between graphs 

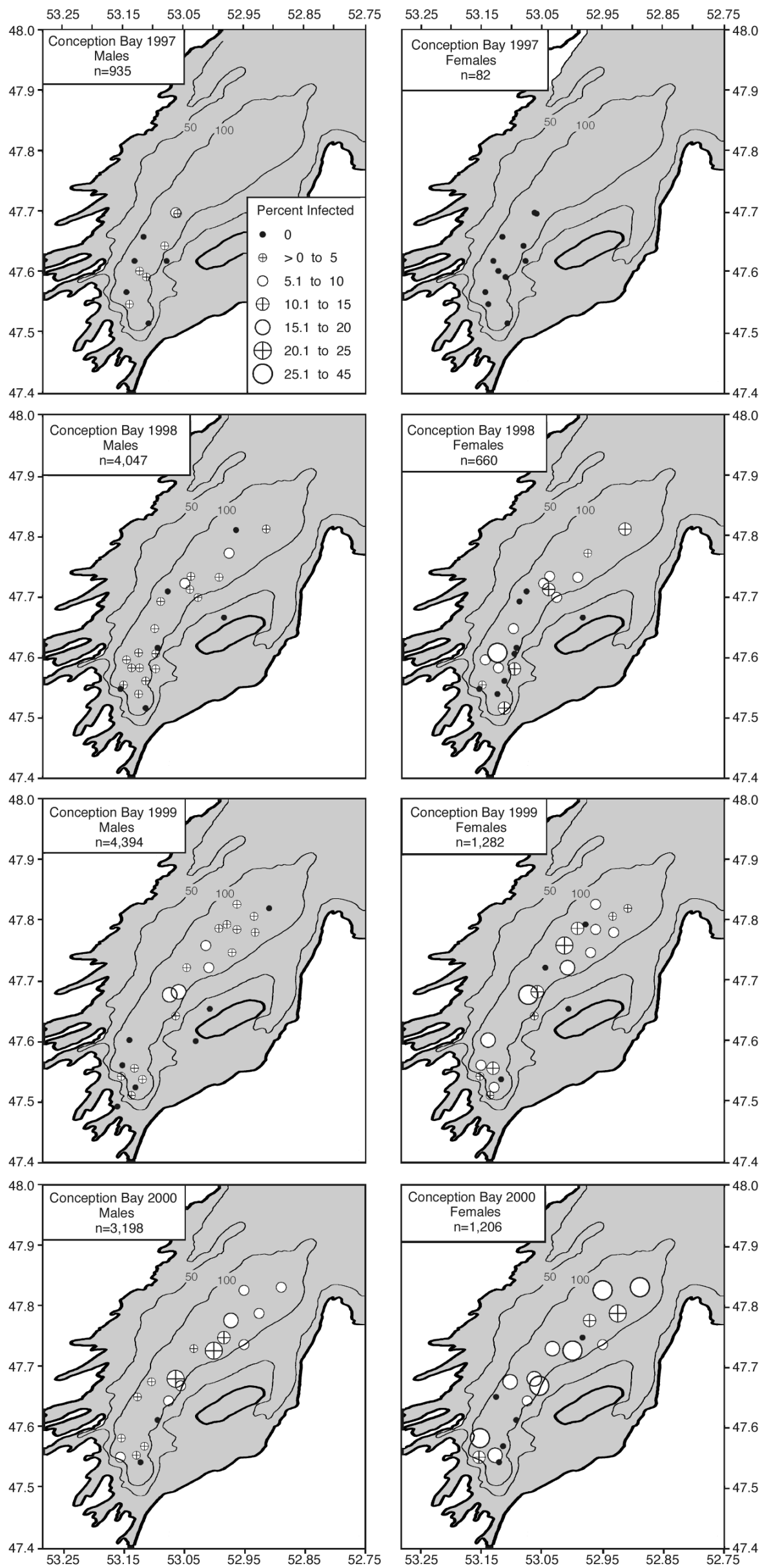

Fig. 3. Hematodinium sp. infecting Chionoecetes opilio. Spatial distribution of BCD in trawls from Conception Bay over time. Prevalence is shown by the size and fill of each circle. Note the clustering in the deeper waters in the bay 
crabs which are known to have a higher prevalence than adult males (Pestal et al. 2003). Trap surveys were biased toward large adult males, whereas trawl surveys showed less bias. There was sufficient data to make 28 temporal comparisons (annually by location and sex) between trap and trawl surveys. In 17 of 28 cases, prevalences were higher in trawls than comparable trap surveys. Prevalences were lower in trawls than traps in 7 of 28 cases. In 4 comparisons, prevalence did not differ between method of capture. In the 7 trawl surveys showing lower prevalences, nearly all were trap samples that had relatively small sample sizes of females skewed by the presence of relatively more infected animals. In general, prevalences were 2.4 times higher in trawl surveys than in trap surveys, but the overall variance was high.

\section{Biotic and abiotic factors}

To determine whether size of crab was associated with prevalence of bitter crab disease, we examined size-frequency distributions of infected and uninfected crabs collected by trawl from Conception Bay for 1997 to 2000 (Fig. 4). The prevalence of infection was highest in small ( $<70 \mathrm{~mm} \mathrm{CW})$ male and female crabs, with most infections found in individuals $<50 \mathrm{~mm}$ in carapace width. Prevalences peaked at around $20 \%$ for $40 \mathrm{~mm}$ crabs of both sexes and were consistently over $10 \%$ in the 25 through $40 \mathrm{~mm}$ size classes. This relationship was consistent for other years. In all cases, large males had substantially lower prevalences than small males and females (see also below). In addition, immature females had a significantly higher prevalence than mature females (15.299 vs. $2.925 \%$, respectively, $\chi^{2}=94.15$, df $=1, \mathrm{p}<0.001, \mathrm{n}=3229$ ), even though their size distributions overlapped significantly.

The prevalence of infection differed significantly across shell types in Conception Bay from 1997 through 2000. Prevalences were $1.08 \%$ for Shell 1 (recently molted; 1 infected animal), $7.30 \%$ for Shell 2 (molted within last year; 837 infected animals), 0.06\% for Shell 3 (not molted within 2 yr; 1 infected animal), and $0.50 \%$ for Shell 6 (molted within $2 \mathrm{yr}, 12$ infected animals). That is, $98.35 \%$ of the infections occurred in individuals in the Shell 2 condition. This pattern was consistent between years and sites. Due to this strong relationship between shell type and prevalence of $\mathrm{BCD}$, and the resulting lack of infected individuals with shell types 1, 3 and 6, Shell Type was not included as a variable in subsequent logistic regressions.

Preliminary analyses of the effects of biotic factors on the probability of infection with BCD revealed significant interactions between sex, maturity, and carapace width $\left(\chi^{2}=767.43, \mathrm{df}=3, \mathrm{p}<0.001\right)$ indicating that the association between carapace width and maturity stage on probability of BCD infection differed between male and female crabs. Therefore, logistic regression models testing the effects of carapace width and maturity stage on the probability of infection were fit separately for male and female crabs (Tables $2 \& 3$ ). Predicted probabilities of infection for males, immature females, and mature females showed marked contrasts in relation to size (Fig. 5). Carapace width was significantly negatively associated with the probability of infection for male crabs (odds ratio for a $1 \mathrm{~mm}$ increase in $\mathrm{CW}=0.967$ ). However, carapace width was significantly positively associated with the probability of infection for female crabs (odds ratio for a $1 \mathrm{~mm}$ increase in $\mathrm{CW}=1.02$ ). For female crabs there was also a significant effect of maturity stage on probability of BCD infection: the odds of an immature female being infected were 5.6 times the odds of a mature female being infected.

Results of logistic regression suggested that 2 abiotic variables were assocated with the probability of infection (Table 4). To account for possible relationships
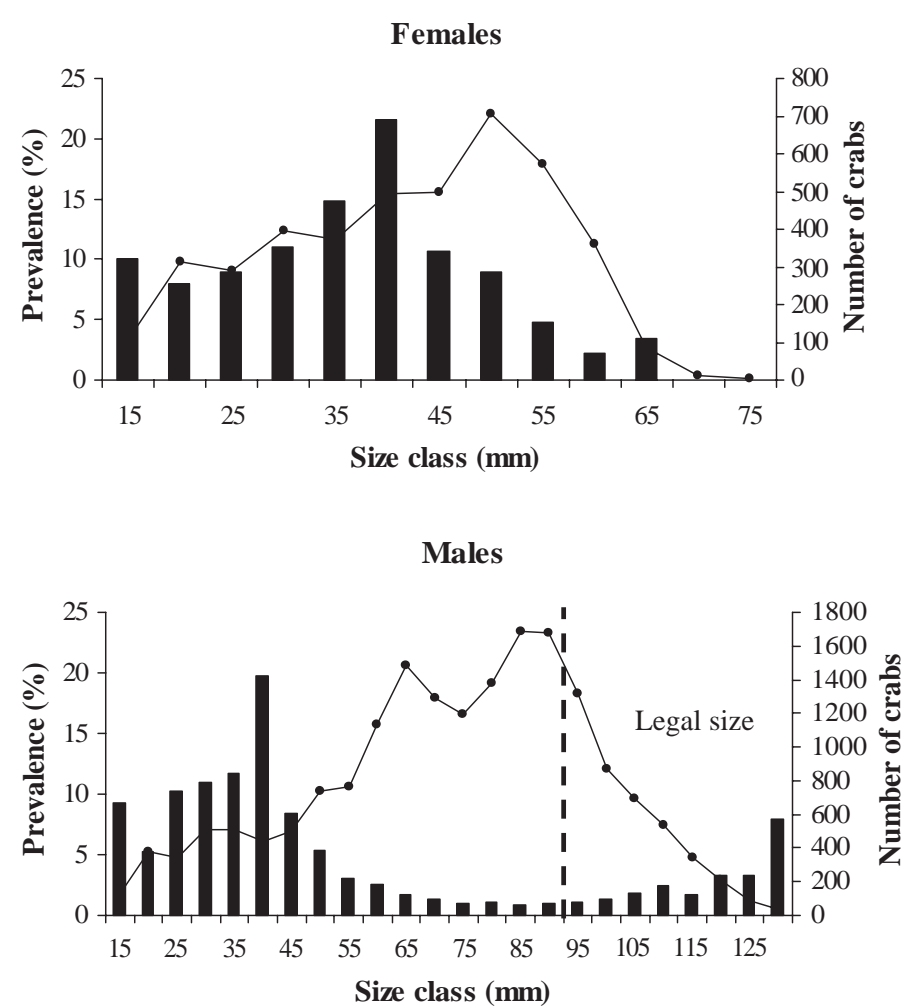

Fig. 4. Hematodinium sp. infecting Chionoecetes opilio. Sizefrequency distributions in $5 \mathrm{~mm}$ classes for male and female crabs from trawl data for Conception Bay, 1997 to 2003. Solid bars $=$ prevalence $(\%)$ of $\mathrm{BCD}$, solid line $=$ number of animals in size class. Note change in scale of $x$-axis between graphs. Dashed line: minimum legal size for males 
Table 2. Estimates for the logistic regression testing the effects of carapace width and maturity stage on probability of infection by bitter crab disease for female snow crabs sampled by trawl from Conception Bay, pooled from 1997 to 2000. Only crabs in Shell 2 (molted within the year) were included. $n=382$ infected, 2513 uninfected. Model chi-square $=69.884 ; \mathrm{df}=2 ; \mathrm{p}<0.001$

\begin{tabular}{|lcrrrrr|}
\hline Parameter & df & Estimate & SE & $t$-ratio & $p$ & Odds ratio \\
\hline Intercept & 1 & -4.158 & 0.385 & -10.793 & $<0.001$ & \\
$\begin{array}{l}\text { Carapace } \\
\text { width }\end{array}$ & 1 & 0.019 & 0.006 & 3.280 & $<0.001$ & $1.02^{\mathrm{a}}$ \\
$\begin{array}{l}\text { Maturity stage } \\
\text { (immature vs. }\end{array}$ & 1 & 1.715 & 0.237 & 7.234 & $<0.001$ & 5.559 \\
$\begin{array}{l}\text { mature) } \\
\text { a Odds ratio for } 1 \mathrm{~mm} \text { increase. Odds ratio for } \mathrm{x} \text { mm increase }=\mathrm{e}^{\mathrm{x}(0.019)}\end{array}$ \\
\hline
\end{tabular}

Table 3. Estimates for the logistic regression testing the effects of carapace width and maturity stage on probability of infection by bitter crab disease for male snow crabs sampled from Conception Bay, pooled from 1997 to 2000. Only crabs in Shell 2 (molted within the year) were included. Maturity was not included for males as chelar measurements to determine maturity status were only recorded for subsets of males in the samples. $\mathrm{n}=455$ infected, 7972 uninfected. Model chi-square $=228.484, \mathrm{df}=1, \mathrm{p}<0.001$

\begin{tabular}{lcccccc|}
\hline Parameter & df & Estimate & SE & $t$-ratio & $p$ & Odds ratio \\
\hline Intercept & 1 & -0.943 & 0.128 & -7.346 & $<0.001$ & \\
Carapace & 1 & -0.034 & 0.002 & -14.207 & $<0.001$ & $0.967^{\mathrm{a}}$ \\
width & & & & & & \\
a Odds ratio for 1 mm increase. Odds ratio for $x$ mm increase $=\mathrm{e}^{\mathrm{x}(-0.034)}$ & \\
\hline
\end{tabular}

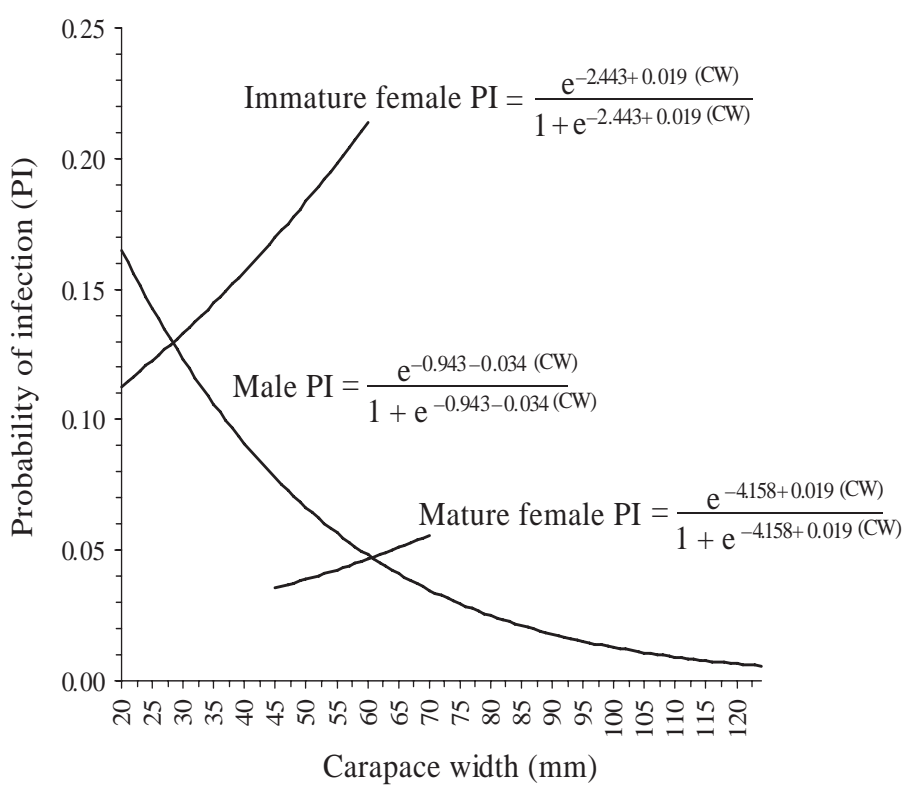

Fig. 5. Hematodinium sp. infecting Chionoecetes opilio. Estimated probability of infection (PI) with $\mathrm{BCD}$ by carapace width (CW) for male, mature female, and immature female snow crabs sampled from Conception Bay between abiotic variables and those biotic variables found to influence the probability of BCD infection, sex/ maturity stage and carapace width were included in the logistic regression models. Depth strata showed a significant association with the probability of infection with higher prevalences occurring at depths $>200 \mathrm{~m}$ (prevalences of 1.44 vs. 3.93 vs. $5.96 \%$ for $<200$, 200 to 250 , > $250 \mathrm{~m}$ depths, respectively). Substrate type showed a significant association with the probability of infection after controlling for the effects of sex, maturity stage, and carapace width. For individuals of any given sex, maturity stage, and carapace width, the odds of an individual sampled from mud/sand substrate being infected with BCD were 2.040 times ( $p$ $=0.030$ ) the odds of an individual sampled from rock/boulder substrate being infected, and 2.446 times $(\mathrm{p}<0.001)$ the odds of an individual sampled from gravel substrate being infected. There was no difference $(p=0.603)$ in the odds of infection between crabs sampled from rock/ boulder substrate and those sampled from gravel/shell substrate. Similarly, crabs from mud/sand bottoms showed significantly higher prevalences than those from gravel or rock/boulder bottoms via contigency table analysis (8.119 vs. 5.551 vs. $2.941 \%$, respectively, $\chi^{2}=21.579, \mathrm{df}=2, \mathrm{p}<0.001$, $\mathrm{n}=10117$ ). However, substrate type also showed significant associations with depth, making it difficult to separate the effects of these variables on prevalence. For example, $100 \%$ of the rock/boulder samples and $94.8 \%$ of the gravel samples were from the 200 to $250 \mathrm{~m}$ depth range, whereas only $59.4 \%$ of the $\mathrm{mud} /$ sand samples were from that depth and $39.3 \%$ were from $>250 \mathrm{~m}$.

\section{Mortality}

The mortality rate for naturally infected individuals differed from those experimentally inoculated or in the control group. However, the mortality study had a small sample size and was exploratory in nature. The median time to death for naturally (overtly) infected snow crabs was $61.8 \pm 7.9$ (SE) d. Naturally infected individuals $(n=12)$ began dying after $2 \mathrm{wk}$ and all of them were dead by Day 99 (Fig. 6). The median time to death for experimentally inoculated crabs was 91.4 
Table 4. Estimates for the logistic regression testing the effects of biotic (a) and abiotic variables (b) on probability of infection by bitter crab disease for snow crabs sampled from Conception Bay, pooled from 1997 to 2000. Because of associations between depth and substrate type, logistic regression was run separately for these variables. $\mathrm{n}=770$ infected; 9347 uninfected

\begin{tabular}{|c|c|c|c|c|c|c|}
\hline Parameter & df & Estimate & SE & $t$-ratio & $\mathrm{p}$ & Odds ratio \\
\hline \multicolumn{7}{|l|}{ (a) } \\
\hline Intercept & 1 & -0.623 & 0.149 & -4.185 & $<0.001$ & \\
\hline \multicolumn{7}{|l|}{ Sex/maturity } \\
\hline $\begin{array}{l}\text { Mature females vs. } \\
\text { males }\end{array}$ & 1 & -0.429 & 2.145 & -0.197 & 0.842 & 0.651 \\
\hline $\begin{array}{l}\text { Immature females } \\
\text { vs. males }\end{array}$ & 1 & -1.364 & 0.297 & -4.595 & $<0.001$ & 0.256 \\
\hline \multicolumn{7}{|l|}{ Carapace width } \\
\hline Males & 1 & -0.036 & 0.003 & -13.928 & $<0.001$ & 0.965 \\
\hline $\begin{array}{l}\text { Immature females } \\
\text { vs. males }\end{array}$ & 1 & 0.050 & 0.007 & 7.311 & $<0.001$ & 1.05 \\
\hline $\begin{array}{l}\text { Mature females vs. } \\
\text { males }\end{array}$ & 1 & 0.002 & 0.039 & 0.054 & 0.953 & 1.002 \\
\hline \multicolumn{7}{|l|}{ Depth } \\
\hline$<200 \mathrm{~m}$ vs. $>250 \mathrm{~m}$ & 1 & -0.641 & 0.400 & -1.602 & 0.109 & 0.527 \\
\hline $200-250 \mathrm{~m}$ vs. $>250 \mathrm{~m}$ & 1 & -0.245 & 0.082 & -3.005 & 0.003 & 0.783 \\
\hline$<200 \mathrm{~m}$ vs. $200-250 \mathrm{~m}$ & 1 & -0.396 & 0.397 & -0.996 & 0.319 & 0.673 \\
\hline \multicolumn{7}{|c|}{ For depth, model chi-square $=489.8, \mathrm{df}=7, \mathrm{p}<0.001$} \\
\hline \multicolumn{6}{|l|}{ Substrate type } & \\
\hline $\begin{array}{l}\text { Mud/sand vs. } \\
\text { rock/boulder }\end{array}$ & 1 & 0.7133 & 0.329 & 2.166 & 0.030 & 2.04 \\
\hline $\begin{array}{l}\text { Gravel vs. } \\
\text { rock/boulder }\end{array}$ & 1 & -0.182 & 0.351 & -0.518 & 0.603 & 0.83 \\
\hline $\begin{array}{l}\text { Mud/sand vs. } \\
\text { gravel }\end{array}$ & 1 & 0.895 & 0.131 & 6.829 & $<0.001$ & 2.446 \\
\hline
\end{tabular}

$\pm 17.0(\mathrm{SE}) \mathrm{d}$. Inoculated crabs $(\mathrm{n}=18)$ experienced $50 \%$ mortality by Day 99, with all of the moribund crabs developing infections of Hematodinium sp., and negligible mortality thereafter to Day 127 when the experiment was terminated. Because the controls exhibited negligible mortalities, the median time to death for the uninfected controls could not be calculated. One of the uninfected controls $(n=8)$ died on Day 54, but no other mortalities occurred in the control treatment. Uninfected control individuals experienced significantly less mortality than naturally infected hosts (log rank test, $\mathrm{p}<0.001, \chi^{2}=15.671$ with $2 \mathrm{df}$ ), but not more than inoculated hosts, albeit the trend was almost significant for the latter (logrank, $\chi^{2}=3.261$ with $1 \mathrm{df}, \mathrm{p}=0.071$ ). Inoculated crabs experienced significantly less mortality than naturally infected hosts (log-rank, $\chi^{2}=7.844$ with 1 df, $\mathrm{p}<0.005)$. None of the control crabs developed infections.

\section{DISCUSSION}

We have documented an apparent increase of bitter crab disease (BCD) in snow crabs in Newfoundland. Once very rare, Hematodinium sp. is now established in the northern bays, and has undergone at least 1 small outbreak in Bonavista and Conception Bays in 1999, and 1 larger epizootic in Conception Bay in 2000. Previous surveys of BCD in Conception Bay have also shown a marked increase in prevalence over time. In the 1992-1993 assessment, prevalences in trapped males were extremely low $(0.037 \%)$ (Taylor \& Khan 1995), but one April sample with a low sample size had a prevalence of $3.7 \%$. In the 1998 fishery assessment, prevalences had increased more than 10 -fold $(0.57 \%)$ and were even higher in trawled males $(1.60 \%)$ (Pestal et al. 2003). The outbreak in 2000 reached a prevalence of over $8 \%$ in trawled males and over $26 \%$ in trapped females. Given that prevalences were based on macroscopic diagnosis of infection, and that Pestal et al. (2003) indicated that macroscopic infections represented approximately $50 \%$ of the actual prevalence during October 1998, the actual prevalence approached $18 \%$ in trapped males and $50 \%$ in trawled females. These are high levels hitherto unreported in Newfoundland. Offshore assessments of BCD typically had much lower prevalences ( 1.0\%) except in 1997 where 2.1 and $4.4 \%$ of males and females were infected (Dawe 2002). Even higher prevalences of $\mathrm{BCD}$ have been reported from focal outbreaks in the Tanner crab fishery from the SE fjords of Alaska, where direct losses were estimated annually at more than US\$250 000 in 1987 (Meyers et al. 1987). In Newfoundland, the foci of BCD are primarily located within the northern bays, which represent approximately 10 to $12 \%$ of the fishery (Anonymous 2002). Whereas direct losses are difficult to estimate for this region, our data show that the disease has a more subtle, indirect effect on the fishery because it is most prevalent in under-sized males and females. Further, all macroscopically infected crabs will die from the infection. Therefore, in Newfoundland the disease has its greatest impact on the pre-recruit and unfished segments of the population. At present, the disease has not been reported from other Maritime Provinces, but 


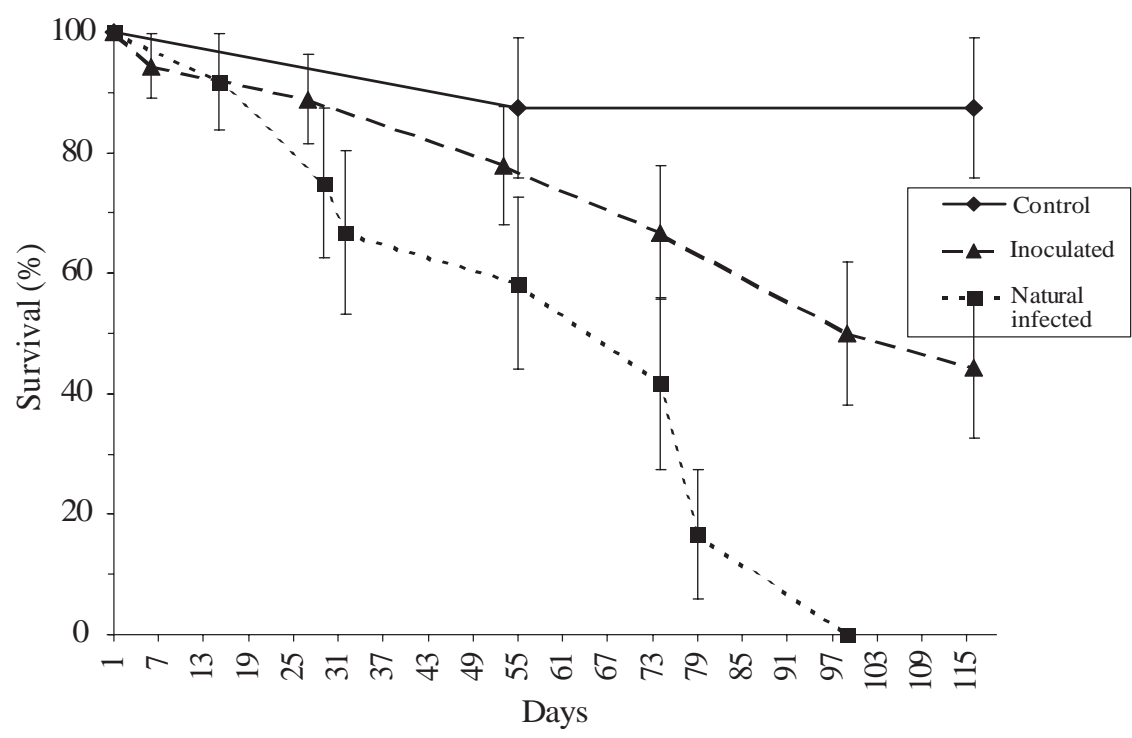

Fig. 6. Hematodinium sp. infecting Chionoecetes opilio. Kaplan-Meier survival analysis of uninfected controls, naturally infected and inoculated crabs over time. The naturally infected crabs had a significantly lower survival than uninfected or inoculated crabs (log rank test, $\mathrm{p}<0.001, \chi^{2}=15.671$ with $2 \mathrm{df}$ ) for monitoring the disease. Similar differences have been noted for BCD in snow crabs from Newfoundland (Pestal et al. 2003) and for Hematodinium sp. in velvet crabs Necora puber off Brittany, France (Wilhelm \& Miahle 1996). In both cases, trawl samples had significantly higher prevalences, presumably because of non-selective sampling of infected and uninfected crabs. However, trawl samples also had a lower minimum size of retention than traps, and at least for snow crabs, prevalences were higher in smaller crabs than in larger crabs. Considering the size of the snow and Tanner crab fisheries, and the relative number of studies on Hematodinium sp. infections in these hosts, it is surprising that differences in gear bias have not been explored for these crustaceans. Further, the disease is most prevalent in the given its rapid spread, other snow crab stocks may be at considerable risk.

Outbreaks of Hematodinium species often occur in constricted areas or areas with entrained water masses such as lagoons, embayments or fjords with shallow sills (Meyers et al. 1987, 1990, Latrouite et al. 1988, Eaton et al. 1991, Field et al. 1992, 1998 Wilhelm \& Miahle 1996, Messick \& Shields 2000). Such associations with physiography and hydrography were first noted for the rhizocephalan Briarosaccus callosus in king crabs (Sloan 1984, Hawkes et al. 1985) and have since been noted for nemertean infestations on king crabs as well (Kuris et al. 1991). In Alaskan fjords, prevalences of BCD reached extremely high levels in Tanner crabs (Meyers et al. 1987, 1990), whereas prevalences in snow crabs from open ocean habitats ranged from very low to moderate (Meyers et al. 1996). Similarly, in Newfoundland, the accumulation of high prevalences and an epizootic outbreak occurred within the relatively constricted confines of Conception Bay, low to moderate prevalences occurred within the less confined Bonavista Bay, and extremely low prevalences occurred within the open ocean environment at the Avalon fishing grounds. Offshore occurrences of BCD in snow crabs reportedly have low prevalences of BCD (Dawe 2002). Our data, combined with the hydrographic affinities of the disease, suggests that once the parasite successfully colonizes hosts within a confined embayment, it will rapidly become enzootic, possibly serving as a locus for the further spread of infections.

The large difference in prevalence between trawl and trap surveys has distinct management implications female and pre-recruit male crabs which are not removed by the fishery and which are not typically monitored by management agencies. Therefore, we recommend that future monitoring for $\mathrm{BCD}$ in Chionoecetes fisheries populations employ less selective or non-selective gear such as trawls or small-mesh traps because prevalences in these under-sampled members of the population may forewarn of an impending epizootic that could be used to predict recruitment failure or impacts on future recruitment to the fishery.

Several other host and environmental factors were clearly associated with BCD in snow crabs from Conception Bay. Host size, sex and molt status (shell type) have been previously associated with infections in Tanner crabs (Meyers et al. 1990, Eaton et al. 1991, Love et al. 1993). However, the disease dynamics in Tanner crabs from Alaska are different from those in snow crabs from Newfoundland. For example, molting of the host appears to be important to transmission of the disease in both host species. In snow crabs from Newfoundland, anecdotal observations based on macroscopically diagnosed BCD infections indicate that the disease is more prevalent in October, well after the end of the commercial fishing season (August 31), and well after the spring peak in molting (D. M. Taylor unpubl. data). Recently molted snow crabs (Shell 1) progress to the Shell 2 stage over the course of 2 to 3 mo and Shell 2 crabs are indicative of a molt within the last 6 to 12 mo (Taylor et al. 1989). Thus, given that $98.35 \%$ of macroscopically overt infections occur within crabs in the Shell 2 condition, and that infections are rare $(1.5 \%)$ in Shell 3 and 6 individuals, 
snow crabs must obtain the infection while in the postmolt condition. In contrast, infected Tanner crabs molt in early spring, before sporulation occurs in infected crabs, and experimental infections take up to 3 mo for infections to be detected, leading Meyers et al. (1990) to speculate that infections may take 15 to 18 mo to develop, and that crabs obtain infections during their molt to the preceding instar. However, in Newfoundland, infected crabs are present in the fishery from the spring through fall as are recently molted animals. Infected crabs in Shell stage 2 have been caught in the spring during the Avalon research cruises (Taylor \& Khan 1995), and these animals likely serve to transmit the disease to the recently molted individuals. Further, infections in snow crabs in Shell 3 and Shell 6 conditions (no molt within 1 to $2 \mathrm{yr}$ ) are rare $(1.5 \%$ ), indicating that few hosts survive infections for more than $1 \mathrm{yr}$. However, in Tanner crabs, 3 to $7 \%$ of infections occur in 'old shell' crabs (viz. Shell 3 and Shell 6 conditions) (Eaton et al. 1991) indicating that either longer infections occur in Tanner crabs, or transmission may have an alternate mode such as diet, cannibalism, or possibly sexual contact (Meyers et al. 1996). While snow crabs do cannibalize each other (Lovrich \& SainteMarie 1997, Squires \& Dawe 2003), and cannibalism may transmit Hematodinium sp. to blue crabs (Sheppard et al. 2003), the extremely low prevalences in the Shell 3 and Shell 6 animals suggest that it is not a contributory factor in the transmission of the parasite. Thus, for snow crabs in Newfoundland, the parasite is most likely transmitted to crabs during molting or while in the post-molt condition. Macroscopically overt infections appear to develop over the course of 2 to 4 mo or longer but rarely persist longer than $1 \mathrm{yr}$. Mortalities likely occur 3 to 6 mo after the infections become macroscopically apparent. Similarly, in the Norway lobster, infections appear to be acquired at molting and develop to patency over 3 to 4 mo (Stentiford et al. 2001).

While there was a potential confound with depth, the relationship between prevalence and substrate type, mud/sand, has not been previously recognized. Dirt, detritus, bivalves and amphipods are often large components of the snow crab diet (Wieczoreck \& Hooper 1995, Squires \& Dawe 2003). Perhaps transmissive stages are ingested by crabs feeding on bivalves which can efficiently filter large quantities of water, hence also ingesting dinospores. Alternatively, amphipods have Hematodinium-like infections (Johnson 1986) and have been posited as potential alternate hosts for crabs (Shields 1994, Messick \& Shields 2000). Several amphipod species co-occur in trawls of snow crabs, but it is not known whether they harbor infections. Lastly, Pestal et al. (2003) showed that depth was related to prevalence of infection, with deeper sites (>250 m) having higher prevalences. In our logistic regression analysis of trawl data, shallow depths $(<200 \mathrm{~m})$ showed much lower prevalences than those $>200 \mathrm{~m}$, with the highest prevalences occurring at $>250 \mathrm{~m}$. Few other studies have assessed depth and substrate type as potential contributory factors in Hematodinium infections. Our data indicate that abiotic factors other than temperature, salinity, and hydrography are also important in the spread of the parasite.

Acknowledgements. We thank Drs. Grant Stentiford and Hamish Small for their critiques. Drs. J. Brian Dempson and J. Morgan reviewed the manuscript for DFO. We are indebted to the captains and crews of the CGS 'Shamook' for their invaluable assistance in collecting snow crabs. The technical staff of the DFO Shellfish section made invaluable field and laboratory contributions to this project. Travel for J.D.S. was supported, in part, by DFO, and in part by NOAA, SaltonstallKennedy Grant NA76FD0148. This is Contribution \#2624 from the Virginia Institute of Marine Science.

\section{LITERATURE CITED}

Agresti A (1996) An introduction to categorical data analysis. New York, Wiley

Anonymous (2002) Commercial quota reports. Statistical Services, DFO Canada, www.dfo-mpo.gc.ca/communic/statistics/commercial/ quota_reports/2002/crab_e.htm

Appleton PL, Vickerman K (1998) In vitro cultivation and development cycle in culture of a parasitic dinoflagellate (Hematodinium sp.) associated with mortality of the Norway lobster (Nephrops norvegicus) in British waters. Parasitology 116:115-130

Bower SM, Meyer GR, Phillips A, Workman G, Clark D (2003) New host and range extension of bitter crab syndrome in Chionoectes spp. caused by Hematodinium sp. Bull Eur Assoc Fish Pathol 23:86-91

Cox DR, Oakes D (1984) Analysis of survival data. Chapman \& Hall, New York

Dawe EG (2002) Trends in prevalence of bitter crab disease caused by Hematodinium sp. in snow crab (Chionoecetes opilio) throughout the Newfoundland and Labrador continental shelf. In: Paul AJ, Dawe EG, Elner R, Jamieson GS and 5 others (eds) Crabs in cold water regions: biology, management, and economics. AK-SG-01-01: University of Alaska Sea Grant, p 385-399

Eaton WD, Love DC, Botelho C, Meyers TR, Imamura K, Koeneman T (1991) Preliminary results on the seasonality and life cycle of the parasitic dinoflagellate causing bitter crab disease in Alaskan tanner crabs (Chionoecetes bairdi). J Invertebr Pathol 57:426-434

Field RH, Appleton PL (1995) A Hematodinium-like dinoflagellate infection of the Norway lobster Nephrops norvegicus: observations on pathology and progression of infection. Dis Aquat Org 22:115-128

Field RH, Chapman CJ, Taylor AC, Neil DM, Vickerman K (1992) Infection of the Norway lobster Nephrops norvegicus by a Hematodinium-like species of dinoflagellate on the west coast of Scotland. Dis Aquat Org 13:1-15

Field RH, Hills JM, Atkinson JA, Magill S, Shanks AM (1998) Distribution and seasonal prevalence of Hematodinium sp. infection of the Norway lobster (Nephrops norvegicus) around the west coast of Scotland. ICES J Mar Sci 55: $846-858$ 
Hawkes CR, Meyers TR, Shirley TC (1985) The prevalence of the rhizocephalan Briarosaccus callosus Boschma, a parasite in blue king crabs, Paralithodes platypus (Brandt), of southeastern Alaska. In: Melteff BR (ed) Proc Int King Crab Symp Anchorage, Alaska, p 353-363

Johnson PT (1986) Parasites of benthic amphipods: dinoflagellates (Duboscquodinida: Syndinidae). Fish Bull 84: 605-614

Kuris AM, Blau SF, Paul AJ, Shields JD, Wickham DE (1991) Infestation by brood symbionts and their impact on egg mortality in the red king crab, Paralithodes camtschatica, in Alaska: geographic and temporal variation. Can J Fish Aquat Sci 48:559-568

Latrouite D, Morizur Y, Noël P, Chagot D, Wilhelm G (1988) Mortalité du tourteau Cancer pagurus provoquée par le dinoflagelle parasite: Hematodinium sp. Int Counc Explor Sea CM ICES/K:32

Love DC, Rice SD, Moles DA, Eaton WD (1993) Seasonal prevalence and intensity of bitter crab dinoflagellate infection and host mortality in Alaskan tanner crabs Chionoecetes bairdi from Auke Bay, Alaska, USA. Dis Aquat Org 15:1-7

Lovrich GA, Sainte-Marie B (1997) Cannibalism in the snow crab, Chionoecetes opilio (O. Fabricius) (Brachyura: Majidae), and its potential importance to recruitment. J Exp Mar Biol Ecol 211:225-245

Messick GA (1994) Hematodinium perezi infections in adult and juvenile blue crabs Callinectes sapidus from coastal bays of Maryland and Virginia, USA. Dis Aquat Org 19: $77-82$

Messick GA, Shields JD (2000) Epizootiology of the parasitic dinoflagellate, Hematodinium sp. in the American blue crab Callinectes sapidus. Dis Aquat Org 43:139-152

Messick GA, Jordan SJ, Van Heukelem WF (1999) Salinity and temperature effects on Hematodinium sp. in the blue crab Callinectes sapidus. J Shellfish Res 18:657-662

Meyers TR, Koeneman TM, Botelho C, Short S (1987) Bitter crab disease: a fatal dinoflagellate infection and marketing problem for Alaskan Tanner crabs Chionoecetes bairdi. Dis Aquat Org 3:195-216

Meyers TR, Botelho C, Koeneman TM, Short S, Imamura K (1990) Distribution of bitter crab dinoflagellate syndrome in southeast Alaskan Tanner crabs Chionoecetes bairdi. Dis Aquat Org 9:37-43

Meyers TR, Morado JF, Sparks AK, Bishop GH, Pearson T, Urban D, Jackson D (1996) Distribution of bitter crab syndrome in Tanner crabs (Chionoecetes bairdi, C. opilio) from the Gulf of Alaska and Bering Sea. Dis Aquat Org 26:221-227

Pestal GP, Taylor DM, Hoenig JM, Shields JD, Pickavance R (2003) Monitoring the presence of the lethal parasite

Editorial responsibility: Timothy Flegel, Bangkok, Thailand
Hematodinium sp. in snow crabs from Newfoundland. Dis Aquat Org 53:67-75

Presnell JK, Schreibmann MP (1997) Humason's Animal Tissue Techniqes, 5th edn. John Hopkins University Press, Baltimore

Sheppard M, Walker A, Frischer ME, Lee RF (2003) Histopathology and prevalence of the parasitic dinoflagellate Hematodinium sp., in crabs (Callinectes sapidus, Callinectes similis, Neopanope sayi, Libinia emarginata, Menippe mercenaria) from a Georgia estuary. J Shellfish Res 22:873-880

Shields JD (1994) The parasitic dinoflagellates of marine Crustacea. Annu Rev Fish Dis 4:241-271

Shields JD, Squyars CM (2000) Mortality and hematology of blue crabs, Callinectes sapidus, experimentally infected with the parasitic dinoflagellate Hematodinium perezi. Fish Bull 98:139-152

Sloan NA (1984) Incidence and effects of parasitism by the rhizocephalan barnacle, Briarosaccus callosus Boschma, in the golden king crab, Lithodes aequispina Benedict, from deep fjords in northern British Columbia, Canada. J Exp Mar Biol 84:111-131

Squires HJ, Dawe EG (2003) Stomach contents of snow crab (Chionoecetes opilio, Decapoda, Brachyura) from the northeast Newfoundland shelf. J Northwest Atl Fish Sci $32: 27-38$

Stentiford GD, Neil DM, Atkinson RJA (2001) The relationship of Hematodinium infection prevalence in a Scottish Nephrops norvegicus population to season, moulting and sex. ICES J Mar Sci 58:814-823

Stentiford GD, Green M, Bateman K, Small HJ, Neil DM, Feist SW (2002) Infection by a Hematodinium-like parasitic dinoflagellate causes Pink Crab Disease (PCD) in the edible crab Cancer pagurus. J Invertebr Pathol 79:179-191

Taylor DM, Khan RA (1995) Observations on the occurrence of Hematodinium sp. (Dinoflagellata: Syndinidae), the causative agent of bitter crab disease in Newfoundland snow crab (Chionoecetes opilio). J Invertebr Pathol 65: 283-288

Taylor DM, Marshall GW, O'Keefe PG (1989) Shell hardening in snow crab tagged in soft-shelled condition. North Am J Fish Manage 9:504-508

Wieczoreck SK, Hooper RG (1995) Relationship between diet and food availability in the snow crab Chionoecetes opilio (O. Fabricius) in Bonne Bay, Newfoundland. J Crustac Biol 15:236-247

Wilhelm G, Mialhe E (1996) Dinoflagellate infection associated with the decline of Necora puber crab populations in France. Dis Aquat Org 26:213-219

Wilkinson L (1997) SYSTAT 7.0: new statistics. SPSS, Chicago

Submitted: July 27, 2004; Accepted: October 13, 2004

Proofs received from author(s): April 5, 2005 